\title{
Anticorrosion coatings based on novel acrylate binders containing $\mathrm{MeO}$ nanoparticles
}

\author{
Steinerová D., Kalendová A., Machotová J., Kohl M. \\ Department of Chemistry and Technology of Macromolecular Materials, University of Pardubice \\ E-mail: steinerovadenisa@gmail.com
}

Water based paints are increasingly attracting interest mainly with a view to reducing air pollution with volatile organic compounds (VOC). However, the protective properties of water-based paints are inferior to those of solvent-based paints and so new ways to increase the resistance of water-based systems are sought. The present contribution describes the preparation and testing of environmentally friendly anticorrosion paints based on novel water-based self-crosslinking acrylate latexes containing appropriate pigments and $\mathrm{ZnO}$ or $\mathrm{MgO}$ nanoparticles at a concentration of $1.5 \%$ (with respect to the monomers) compared to the same systems free from the nanoparticles. Both the effect of the $\mathrm{MeO}$ nanoparticles and the effects of the pigment species and particle shapes on the paint film properties were examined. The $\mathrm{MeO}$ nanoparticles were found to improve all the properties tested. The latexes with $\mathrm{MgO}$ exhibited the highest resistance to flash corrosion while the latexes with $\mathrm{ZnO}$ exhibited the highest anticorrosion resistance. Furthermore, the systems with the calcium-aluminium polyphosphosilicate based pigment were superior to all the remaining systems in this respect. It is concluded that binders with nanoparticles can be used as a basis for anticorrosion coatings provided that a suitable pigment is selected.

\section{INTRODUCTION}

Volatile organic compounds (VOC) are emitted as gases from solvent-based paints not only during the film formation process but also long thereafter. VOC include various chemicals, some of which can have short-term or long-term impacts on human health and the environment, and so pressure is exerted on paint specialists and painters to develop and use water-based, i.e. low-VOC or VOC-free paints. Water-based paints are environmentally friendly in that they meet both US (EPA - U.S. Environmental Protection Agency) and European (BPD - Biocidal Products Directive) regulations requiring that the $\mathrm{VOC}$ concentration be lower than $350 \mathrm{~g}$ per litre water [1]. Acrylate based water-dilutable paints are a universal, high-quality and environmentally friendly choice for surface protection of both metallic and non-metallic materials. Their synthesis has been mastered very well [2].
Latex paint films are formed through physical combination (coalescence) of thermoplastic polymeric particles, and the quality of the coalescence plays the decisive role in the paint film properties. Physical crosslinking, however, is inferior to chemical crosslinking which provides a considerably higher paint film quality and better use properties. Hence, it is appropriate to reinforce the crosslinking process with ketohydrazide post-crosslinking, which is a process based on a reaction between the carbonyl group in diacetone acrylamide (DAAM), included in the polymeric chain, and the hydrazide group in adipic dihydrazide (ADH), dissolved in the aqueous phase (see Fig. 1). The film formation process itself is accompanied by elimination of water and decrease in $\mathrm{pH}$ due to evaporation of ammonia or amines [3]. The crosslinking reaction takes place near the particle surface, resulting in inter-particle crosslinking during the film formation. Such latexes can find use in a wide range of industries, from the building industry to the wood industry to decorative coatings. Their main assets compared to conventional crosslinking dispersions include a fast reaction proceeding also at room temperature, reduced tack at elevated temperatures and lower brittleness at low temperatures [4].

Disadvantages of water-based paints include a poorer anticorrosion resistance and the occurrence of flash corrosion on the substrate metal - a phenomenon occurring only with water-soluble coating materials [6]. If water evaporation from the paint film is slow, e.g. due to high air humidity, then the coalescence is preceded by soluble iron salt elution and transport to the paint film [7]. Metal corrosion is a natural process resulting in a loss or damage of the material structure, associated with poorer use properties or complete damage of the material. Coating with protective paints is the most widely used way to protect metals against corrosion because this approach is less expensive and easier to perform than plating or the use of stainless materials. Also, paints offer a wide selection of properties. The protective properties of paints consist mainly in metal 


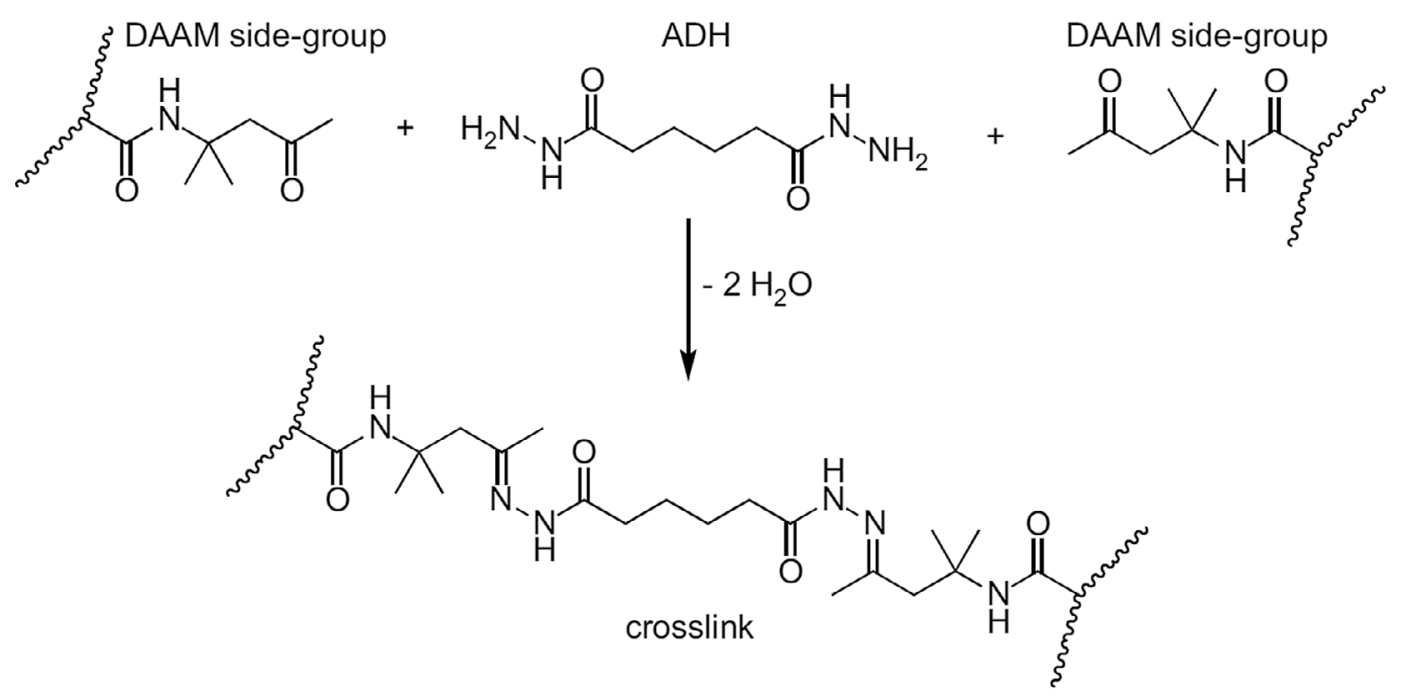

Fig. 1. Reaction scheme of keto-dihydrazide post-crosslinking [5]

isolation from the outer environment (barrier effect), and in an inhibitory effect where anticorrosion pigments are used, providing also cathodic protection [8]. As mentioned above, the anticorrosion coating industry is undergoing change driven by efforts to protect the environment and use both environmentally friendly products and environmentally friendly industrial processes. The use of lead-based or chromium(VI)-based anticorrosion pigments has been banned. This fact stimulates vigorous research because the above pigments represented the core of many anticorrosion paints possessing very good properties. So, focus is on search for new pigments possessing comparable properties while posing no health hazard or environmental hazard [9].

The incorporation of nanoparticles offers a new way to enhance the paint film's use properties because both $\mathrm{ZnO}$ and $\mathrm{MgO}$ nanoparticles are sparingly soluble in water $\left(\mathrm{ZnO}: 0.00016 \mathrm{~g}\right.$ in $100 \mathrm{ml}$ at $20^{\circ} \mathrm{C}$; $\mathrm{MgO}$ : $0.0086 \mathrm{~g}$ in $100 \mathrm{ml}$ at $30^{\circ} \mathrm{C}$ ), and the metal cations present can stimulate additional crosslinking, called ionomeric, with the carboxy groups bonded on the polymeric chains. Nanoparticle incorporation during the synthesis supports uniform nanoparticle dispersion in the aqueous phase among the particles of the copolymers.

\section{EXPERIMENTAL}

\section{Synthesis and characterization of the acrylate dispersions}

The starting monomers used in the synthesis included methyl methacrylate (MMA), $n$-butyl acrylate (BA), methacrylic acid (KMA) and diacetone acrylamide (DAAM), all from Sigma-Aldrich, Czech Republic. The crosslinking agent was adipic dihydrazide (ADH, active substance content $>98 \%$ ), also from Sigma-Aldrich, Czech Republic. Disponil FES 993 (a fatty alcohol polyglycol ether sulphate, sodium salt; BASF, Czech Republic) served as the emulsifier; and ammonium peroxodisulphate (active substance content $>99.9 \%$; Lach-Ner, Czech Republic) served as the initiator. The nanoparticles (particle size $<200 \mathrm{~nm}$, no surface pretreatment) consisted of nanostructural $\mathrm{MgO}$, active substance content $>98 \%$, commercial name JR-NMg30, manufactured by Xuancheng Jingrui New Materials Co., China, or nanostructural $\mathrm{ZnO}$, active substance content $>99 \%$, manufactured by Alfa Aesar, USA. The synthesis consisted of two-stage (semi-continuous) emulsion radical polymerization. The precise polymer composition is listed in Table 1. The self-crosslinking aqueous dispersions were obtained by mixing with a $10 \%$ aqueous solution of $\mathrm{ADH}$ in amounts providing the DAAM-to-ADH molar ratio of $2: 1$, followed by alkalinisation with $10 \%$ aqueous ammonia to $\mathrm{pH}=8.4-8.5$ (except for latex containing nanoparticles $\mathrm{MgO}$ ).

Tab. 1. The ratio of monomers and nanoparticles of latex dispersions

\begin{tabular}{|c|c|c|}
\hline Sample* & $\begin{array}{c}\text { 1. phase }[g] \\
\text { MMA/BA/KMA }\end{array}$ & $\begin{array}{c}\text { 2. phase }[\mathbf{g}] \\
\text { MMA/BA/KMA/DAAM/MeO }\end{array}$ \\
\hline LM & $86 / 106 / 8$ & $72 / 104 / 8 / 10 / 6$ \\
\hline LZ & $86 / 106 / 8$ & $72 / 104 / 8 / 10 / 6$ \\
\hline L0 & $86 / 106 / 8$ & $72 / 104 / 8 / 10 / 0$ \\
\hline
\end{tabular}

* LM - latex containing nanoparticles $\mathrm{MgO}, \mathrm{LZ}$ - latex containing nanoparticles $\mathrm{ZnO}$, LO - latex without nanoparticles

The self-crosslinking dispersion were analysed to determine the coagulate and coarse impurity contents by sieve analysis as per ČSN 649008 ; the non-volatile matter content as per ČSN EN ISO 3251; pH as per ČSN ISO 976 (by using a Mettler Toledo FiveEasy FE20 pH-meter, Merck KGaA, Germany); non-Newtonian (apparent) 
Tab. 2. Basic properties of evaluated binders

\begin{tabular}{|c|c|c|c|c|c|c|c|}
\hline Sample & $\begin{array}{c}\text { Coagulate } \\
\text { content [\%] }\end{array}$ & $\begin{array}{c}\text { Non-volatile } \\
\text { content [\%] }\end{array}$ & $\begin{array}{c}\mathbf{p H} \\
{[-]}\end{array}$ & $\begin{array}{c}\text { Apparent viscosity } \\
{[\mathbf{m P a . s}]}\end{array}$ & $\begin{array}{c}\text { Density } \\
{\left[\mathbf{g . c m}^{-3}\right]}\end{array}$ & $\begin{array}{c}\text { MFFT } \\
{\left[{ }^{\circ} \mathbf{C}\right]}\end{array}$ & $\begin{array}{c}\text { Real nanoparticle content } \\
\text { in film [\%] }\end{array}$ \\
\hline LM & 2.98 & 42.58 & 10.34 & 90.86 & 1.05 & 1.9 & 1.22 \\
\hline LZ & 0.62 & 43.86 & 8.38 & 58.53 & 1.03 & 7.1 & 1.31 \\
\hline L0 & 0 & 40.98 & 8.44 & 30.97 & 1.01 & 5.8 & 0 \\
\hline
\end{tabular}

viscosity on a RotoVisco RT10/94 viscometer (HAAKE, Germany) in the cone/plate arrangement (Searle type) at $21{ }^{\circ} \mathrm{C}$ (maintained with a Thermo Scientific Haake A10 instrument, Thermo Fisher Scientific, USA); binder density by pycnometric measurement as per ČSN EN ISO 2811-1; the minimum film forming temperature as per ISO 2115 (on an MFFT-60 instrument, Rhopoint Instruments, England); and the actual nanoparticle content in the paint film by inductively coupled plasma atomic emission spectroscopy (ICP-OES) (on a Thermo Scientific iCAP 7000 Series, Thermo Fisher Scientific, Germany). The parameters are summarised in Table 2.

\section{Pigments and fillers}

The following commercial anticorrosion pigments were used: calcium aluminium polyphosphosilicate (trade name HEUCOPHOS ${ }^{\circledR}$ CAPP, role: chemically and electrochemically acting anticorrosion pigment, structure: an aluminium phosphate/calcium silicate $\left(\mathrm{Al}\left(\mathrm{PO}_{4}\right)_{3} /\right.$ $/ \mathrm{CaSiO}_{3}$ ) mixture, $\mathrm{pH}$ : 8.1, manufacturer/supplier: Heubach $\mathrm{GmbH}$, Germany); calcium magnesium phosphate (trade name HEUCOPHOS ${ }^{\circledR}$ CMP, role: chemically and electrochemically acting anticorrosion pigment, structure: a calcium phosphate/magnesium phosphate $\left(\mathrm{Ca}_{3}\left(\mathrm{PO}_{4}\right)_{2} / \mathrm{Mg}_{3}\left(\mathrm{PO}_{4}\right)_{2}\right)$ mixture, pH: 6.5, manufacturer/ supplier: Heubach GmbH, Germany) and calcium hydrogen phosphate (trade name HEUCOPHOS ${ }^{\circledR}$ CHP, role: chemically and electrochemically acting anticorrosion pigment, structure: anhydrous $\mathrm{CaHPO}_{4}, \mathrm{pH}$ : 7.6, manufacturer/supplier: Heubach $\mathrm{GmbH}$, Germany). Plastorit (trade name: Plastorit ${ }^{\circledR}$ Micro, role: pigment for primers, structure: an $\mathrm{SiO}_{2} /(\mathrm{Mg}, \mathrm{Fe}, \mathrm{Li}) \mathrm{AlSi}_{3} \mathrm{O}_{10}(\mathrm{OH})_{8} / \mathrm{Mg}_{3} \mathrm{Si}_{4} \mathrm{O}_{10}$ $(\mathrm{OH})_{2}$ mixture, $\mathrm{pH}$ : 6.3, manufacturer/supplier: Imerys Performance Additives, France) and limestone (trade name Omyacarb - 1VA, role: paint filler, structure: $\mathrm{CaCO}_{3}$, pH: 9.0, manufacturer/supplier: Omya CZ s.r.o., Czech Republic) served as the covering pigments.

\section{Formulation of the anticorrosion paints}

The specific weights of the pigments and fillers were determined on an AutoPycnometer 1320 helium pycnometer (Micromeritics, USA). The oil absorption values were determined by the mortar-pestle method as per ČSN EN ISO 787-5. (The oil number obtained from this value was used to calculate the critical pigment volume concentration, CPVC). The pigment particle size was expressed as the diameter of an equivalent sphere [18] (i.e. a ball dispersing laser radiation to the same extent as the particle in question), measured on a MASTERSIZER 2000 instrument (Malvern Panalytical, UK). The parameters of the pigments and fillers are listed in Table 3.

Tab. 3. Characterization of pigments and fillers

\begin{tabular}{|c|c|c|c|c|}
\hline Pigments* & $\begin{array}{c}\text { Particle size } \\
\mathbf{d}_{\mathbf{5 0}}[\boldsymbol{\mu \mathbf { m } ]}\end{array}$ & $\begin{array}{c}\text { Density } \\
{\left[\mathbf{g . c m}^{-3} \text { ] }\right.}\end{array}$ & $\begin{array}{c}\text { Oil absorption } \\
{\left[\mathbf{g . 1 0 0} \mathbf{~ g}_{\text { } \mathbf{~ I G ~}}\right]}\end{array}$ & $\begin{array}{c}\text { CPVC } \\
{[\mathbf{\%}]}\end{array}$ \\
\hline CAPP & 3.5 & 2.60 & 44.58 & 44.51 \\
\hline CMP & 2.8 & 2.80 & 48.71 & 40.55 \\
\hline CHP & 3.9 & 2.88 & 39.73 & 44.85 \\
\hline P & 5.5 & 2.74 & 27.23 & 55.50 \\
\hline 1VA & 2.1 & 2.94 & 23.84 & 57.07 \\
\hline
\end{tabular}

* Abbreviations of anticorrosive pigments: CAPP - HEUCOPHOS ${ }^{\circledR}$ CAPP, CMP - HEUCOPHOS ${ }^{\circledR}$ CMP, CHP - HEUCOPHOS ${ }^{\circledR}$ CHP, $P$ - Plastorit ${ }^{\circledR}$ Micro, 1VA-Omyacarb - IVA

The anticorrosion paints prepared contained the pigments (CAPP, CMP or CHP) at a pigment volume concentration (PVC) $10 \%$. The pigment Plastorit ${ }^{\circledR}$ Micro was added so that the PVC increased by $2 \%$, and then Omyacarb - 1VA was added to adjust the pigment system parameter at $\mathrm{Q}=50 \%(\mathrm{Q}=100 \%$ at $\mathrm{PVC}=\mathrm{CPVC})$. The dispersions were prepared from high-concentration aqueous pigment pastes on a DISPERMAT Dissolver (Donventa AG, Switzerland). The following ingredients were added to the dispersing vessels: NOPCOSPERSE N (Henkel, Germany) and Dispex ${ }^{\circledR}$ Ultra FA 4480 (BASF, Germany) dispersing additives; DEHYDRAN ${ }^{\circledR}$ defoamer (Henkel, Germany); SER-AD FA179 flash corrosion inhibitor (Sigma-Aldrich, Germany); and BENTONE $^{\circledR}$ EW rheological additive (Elementis, Germany), to ensure appropriate dispersing and obtain defect-free paint films.

\section{Preparation of the anticorrosion paints}

The pigmented paints were applied to steel panels (Q-Panel steel Class. 11 - ISO 3574 CR1; cold rolled low-carbon steel) $102 \times 51 \times 0.8 \mathrm{~mm}$ size for the flash 
corrosion tests and $152 \times 102 \times 0.8 \mathrm{~mm}$ size for the remaining corrosion tests. The panel surface was degreased with chloroform before applying the paint. The paint was applied by using an applicator (a Bird type application ruler, manufacturer: Zehntner, Germany). The slot width was $150 \mu \mathrm{m}$ for the flash corrosion tests while for the remaining corrosion tests the slot width was set at $200 \mu \mathrm{m}$ for the first coat and $250 \mu \mathrm{m}$ for the second and third coats. Each layer was allowed to dry for 48 hours and the complete film was allowed to dry for another 10 days in an air-conditioned room at $(21 \pm 2){ }^{\circ} \mathrm{C}$ and relative humidity $55 \%$ as per ČSN EN 23270 [10].

\section{Evaluation of the anticorrosion paints}

Steel substrate flash corrosion was evaluated by a laboratory test measuring resistance to flash corrosion [11]. For this, the steel panels were painted, allowed to dry at $(21 \pm 2){ }^{\circ} \mathrm{C}$ and $\mathrm{RH}(50 \pm 5) \%$ for 2 hours and then put into a refrigerator at $5{ }^{\circ} \mathrm{C}$ for 16 hours. When removed from the refrigerator, the panels with the paint up were covered uniformly with filter paper soaked in distilled water. Intimate paint contact with the water was achieved by putting a glass pane on top. This system was allowed to stand at room temperature for 2 hours. Subsequently the filter paper was removed, the painted panels were dried, and any corrosion effects were evaluated by comparing with the ASTM D 610-85 scale (see Fig. 2). Although actually designed to evaluate

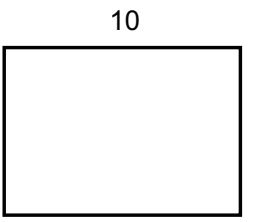

$0.01 \%$

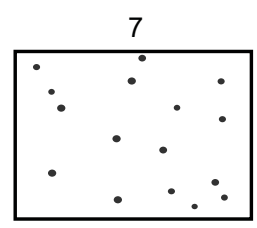

$0.3 \%$

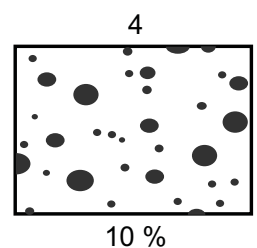

1

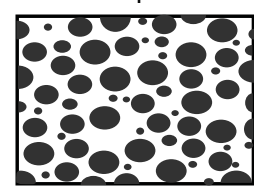

$50 \%$

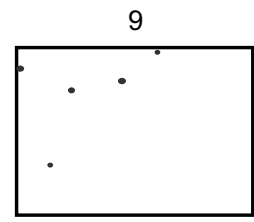

$0.03 \%$
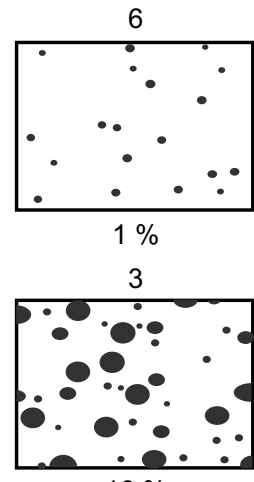

$16 \%$

0

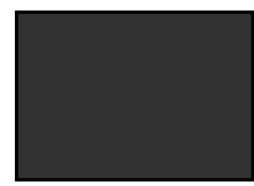

$100 \%$

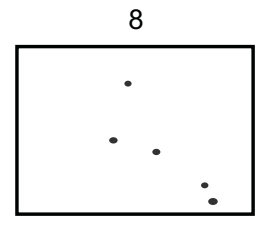

$0.1 \%$
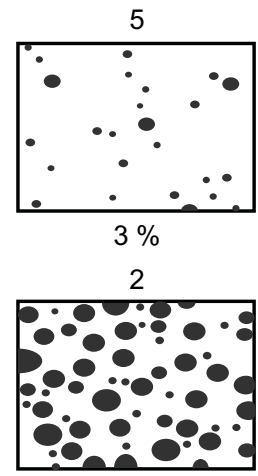

$33 \%$ corrosion beneath a paint film due to atmospheric corrosion, this scale can also be applied with advantage to flash corrosion effects [12].

The paint films were evaluated for corrosion resistance to a humid atmosphere as per ČSN 038131 by using a condensation chamber (Kovofiniš, Czech Republic), in which the coated panels were exposed for 480 hours, and for corrosion resistance to neutral salt spray as per ČSN ISO 9227 by using a SKB400ATR salt chamber (Liebisch, Germany), in which the coated panels were exposed for 360 hours. Once the corrosion effects on the paint films had been evaluated, the films were removed with a paint remover and the corrosion effects on the steel surface were evaluated. The paint film appearance and degree of corrosion were assessed visually, and the results were processed based on ASTM standards. The steel corrosion effects on the paint film surface and on the steel panel surface were assessed as per ASTM D 610-85; the blisters on the paint film surface and in an artificial cut made through the paint film were assessed as per ASTM D 714-87, and corrosion in the cut was assessed as per ASTM D 1654-92. The paint film anticorrosion efficiency was then evaluated from the partial results as per ČSN ISO 2409.

\section{RESULTS AND DISCUSSION}

\section{Resistance to flash corrosion}

No steel surface flash corrosion effects were found with the systems containing magnesium oxide nanoparticles (based on the LM latex), as shown in Table 4. Hence, we conclude that magnesium oxide nanoparticles act as an efficient flash corrosion inhibitor, viz. due to the dissolution of a fraction of the oxide, causing a latex alkalinity increase to $\mathrm{pH}>10$ (see Table 2). Owing to this alkalinity, the potential was shifted to a region where the steel surface corrosion was suppressed, in line with the Pourbaix diagram [13]. The results also demonstrated that the presence of the pigments had no

Tab. 4. Resistance of paint films to flash corrosion

\begin{tabular}{|c|c|c|c|}
\hline \multicolumn{2}{|c|}{ System } & \multicolumn{2}{c|}{ Flash corrosion [\%] } \\
\hline Binder & Pigment & After 2 hours & Throughout the cycle \\
\hline \multirow{4}{*}{ LM } & CAPP & 0.01 & 0.01 \\
\cline { 2 - 4 } & CHP & 0.01 & 0.01 \\
\cline { 2 - 4 } & CMP & 0.01 & 0.01 \\
\hline \multirow{4}{*}{ LZ } & CAPP & 0.03 & 33 \\
\cline { 2 - 4 } & CHP & 0.1 & 33 \\
\cline { 2 - 4 } & CMP & 0.03 & 16 \\
\hline \multirow{3}{*}{ L0 } & CAPP & 0.1 & 33 \\
\cline { 2 - 4 } & CHP & 0.03 & 50 \\
\cline { 2 - 4 } & CMP & 0.03 & 33 \\
\hline
\end{tabular}

Fig. 2. Corrosion scale according to ASTM D 610-85 [12] 
significant effect on the coating system resistance to flash corrosion, and so a flash corrosion inhibitor was added to the LZ and L0 based systems for the corrosion tests.

\section{Resistance to the humid atmosphere}

The paint films thickness on the steel panels was $100 \pm 10 \mu \mathrm{m}$ for the resistance tests against the humid atmosphere and a test cut was made through the paint film, as mentioned above. The coated panels were exposed to an atmosphere with $100 \%$ humidity at $(38 \pm 2){ }^{\circ} \mathrm{C}$ for 480 hours. The results (see Fig. 3) demonstrate that the resistance to the humid atmosphere is nearly unaffected by the presence of the nanoparticles. This implies that no significant increase in the formation of interstitial compartments causing water diffusion into the paint film is stimulated by the dissolution of a fraction of the $\mathrm{MeO}$ nanoparticles. None of the samples exhibited appreciable corrosion in the cut or steel corrosion effects on the paint film surface. The results of the overall corrosion resistance to the humid atmosphere mirror primarily corrosion on the steel substrate surface and blistering on the paint film surface, both of them due to water diffusion into the paint film due to the presence of interstitial compartments containing residues of the emulsifier and initiator, and also (in the latexes with the nanoparticles) a small amount of dissolved $\mathrm{MeO}$. The efficiency of the pigments was found to decrease in order calcium aluminium polyphosphosilicate (CAPP) $>$ $>$ calcium magnesium phosphate $(\mathrm{CMP})>$ calcium hydrogen phosphate (CHP) in all of the systems.

\section{Resistance to neutral salt spray}

The resistance of the anticorrosion coatings to neutral salt spray was evaluated on steel panels coated with paint films $100 \pm 10 \mu \mathrm{m}$ thick and provided with tests cuts. The coated steel panels were exposed to a $5 \%$ salt fog at $(35 \pm 1){ }^{\circ} \mathrm{C}$ and an enhanced air humidity for 360 hours. The results are summarised in Table 5.

All of the systems exhibited the highest resistance if pigmented with the calcium aluminium polyphosphosilicate based pigment (CAPP) (see Fig. 4). The results show that an addition of $\mathrm{MeO}$ nanoparticles invariably increased the resistance of the pigmented paint films to the neutral salt fog, primarily mirroring the enhanced resistance to the steel corrosion effects on the

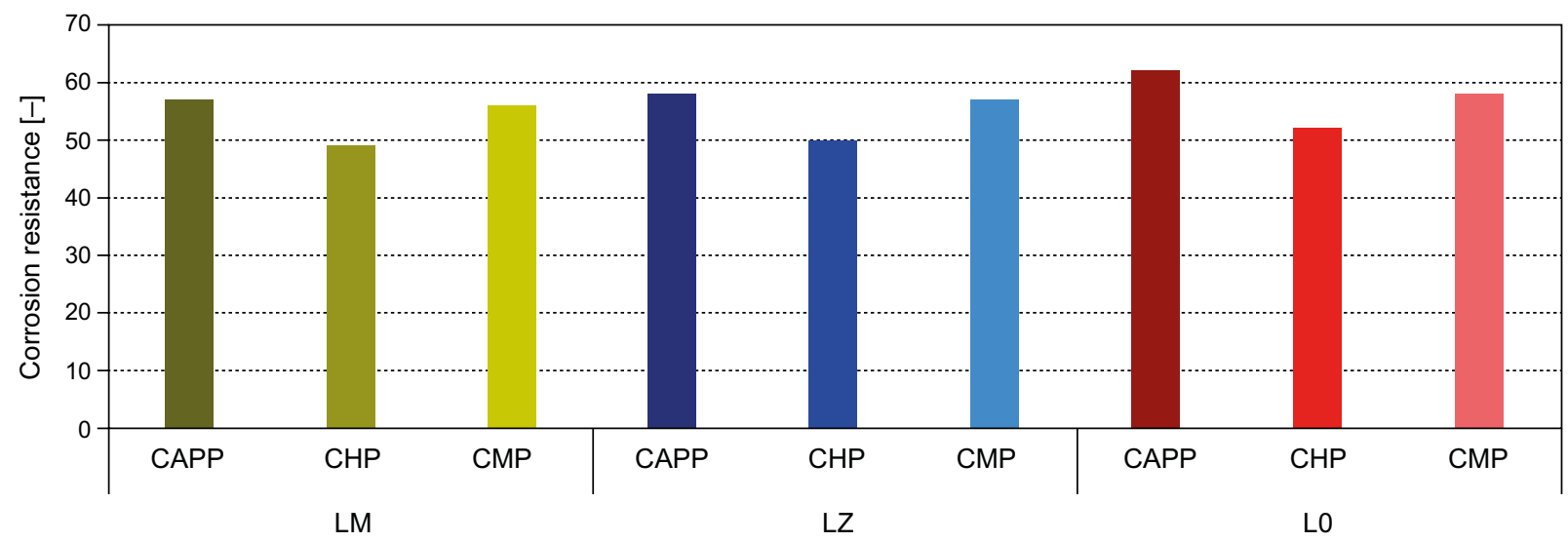

Fig. 3. Total corrosion resistence to humid atmospheres for 480 hours exposure

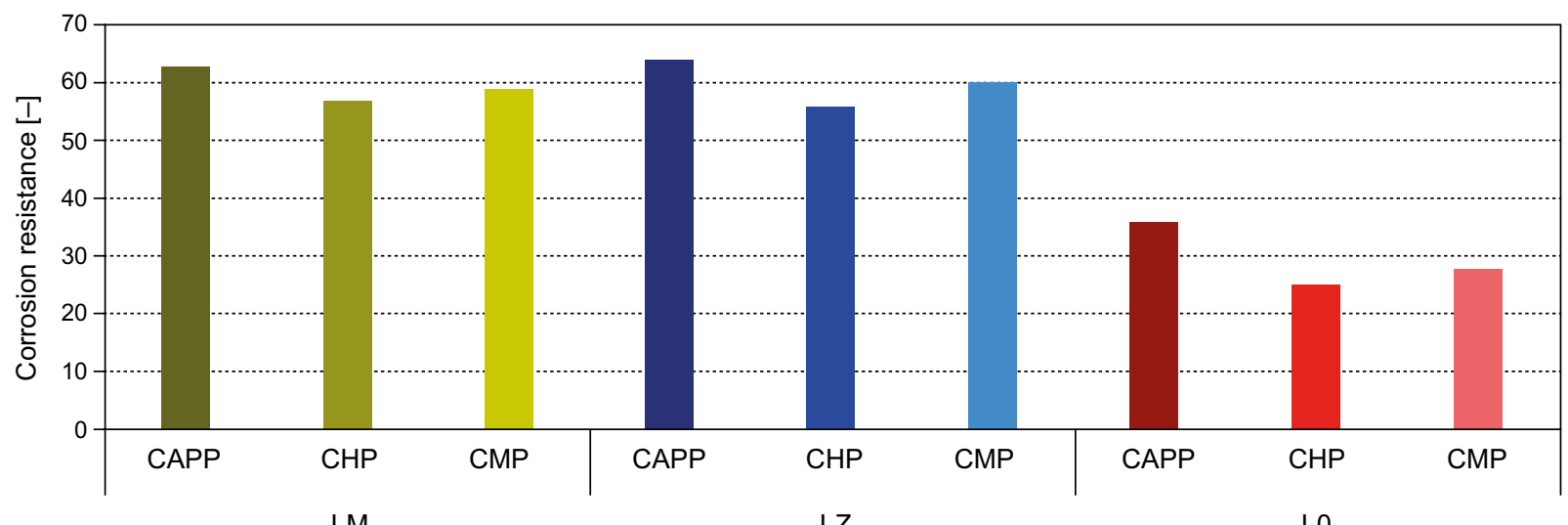

$L M$

LZ

L0

Fig. 4. Total corrosion resistence to neutral salt spray afret 360 hours exposure 
Tab. 5. Resistance of the anticorrosion paints against neutral salt spray after 360 hours exposure

\begin{tabular}{|c|c|c|c|c|c|c|}
\hline \multicolumn{2}{|c|}{ System } & \multirow{2}{*}{$\begin{array}{l}\text { Osmotic blisters of } \\
\text { paint film [-] }\end{array}$} & \multirow{2}{*}{$\begin{array}{l}\text { Rusting on surface } \\
\text { paint film [\%] }\end{array}$} & \multirow{2}{*}{$\begin{array}{l}\text { Corrosion of metal } \\
\text { substrate [\%] }\end{array}$} & \multirow{2}{*}{$\begin{array}{l}\text { Corrosion } \\
\text { in cut }[\mathrm{mm}]\end{array}$} & \multirow{2}{*}{$\begin{array}{l}\text { Osmotic blisters } \\
\text { in cut }[-]\end{array}$} \\
\hline Binder & Pigment & & & & & \\
\hline \multirow{3}{*}{ LM } & CAPP & $6 \mathrm{M}$ & 1 & 16 & 0.3 & $8 \mathrm{M}$ \\
\hline & $\mathrm{CHP}$ & $6 \mathrm{MD}$ & 3 & 16 & 0.3 & $8 \mathrm{M}$ \\
\hline & CMP & $6 \mathrm{M}$ & 10 & 16 & 0.2 & $8 \mathrm{M}$ \\
\hline \multirow{3}{*}{$\mathrm{LZ}$} & CAPP & $6 \mathrm{M}$ & 10 & 16 & 0 & $6 \mathrm{~F}$ \\
\hline & $\mathrm{CHP}$ & $6 \mathrm{M}$ & 16 & 33 & 0 & $6 \mathrm{~F}$ \\
\hline & CMP & $6 \mathrm{MD}$ & 10 & 33 & 0.1 & 0 \\
\hline \multirow{3}{*}{ L0 } & CAPP & $6 \mathrm{D}$ & 33 & $>50$ & 0 & $6 \mathrm{M}$ \\
\hline & CHP & $4 \mathrm{D}$ & $>50$ & $>50$ & 0.5 & $6 \mathrm{MD}$ \\
\hline & CMP & $6 \mathrm{D}$ & $>50$ & $>50$ & 0 & $6 \mathrm{MD}$ \\
\hline
\end{tabular}

paint film surface and to corrosion of the steel substrate surface. A comparison with the results obtained from the humid atmosphere test suggests that here, also, the corrosion resistance is reduced by the presence of a high concentration of atmospheric water, bringing about aqueous solution diffusion into the paint film.

\section{CONCLUSION}

This work focused on the investigation of environmentally friendly anticorrosion coatings based on watersoluble self-crosslinking acrylate dispersion containing $\mathrm{ZnO}$ or $\mathrm{MgO}$ nanoparticles at a concentration of $1.5 \%$ with respect to the monomers, using the same latexes free from the nanoparticles as the reference systems. Three industrial anticorrosion pigments possessing different chemical compositions were added to the systems and the effects of both the nanoparticles and the pigments were examined. The LM based coatings exhibited outstanding resistance to flash corrosion. The resistance to neutral salt spray was improved by the presence of the $\mathrm{MeO}$ nanoparticles, particularly $\mathrm{ZnO}$, whereas the resistance to a humid atmosphere remained unaffected by the presence of the nanoparticles. As to the corrosion inhibition efficiency of the pigments, the highest efficiency was observed with calcium aluminium polyphosphosilicate (P-CAPP). The reason may be favourable $\mathrm{pH}$, partial solubility, suitable shape for arrangement of solid particles and possible synergistic effect with $\mathrm{MeO}$ nanoparticles in polymer coating film.

\section{REFERENCES}

1. Směrnice Evropského parlamentu a Rady 2004/42/ES: o omezování emisí těkavých organických sloučenin vzni- kajících při používání organických rozpouštědel v některých barvách a lacích a výrobcích pro opravy nátěru vozidel a o změně směrnice 1999/13/ES; 2004.

2. Machotová J., Černošková E., Rückerová A. et al.: Control of surface properties of transparent waterborne lacquers based on acrylic latexes. Pardubice: Chemagazin, 2017. ISBN 978-80-906269-2-8.

3. Machotová J., Rückerová A., Kalendová A. et al.: Waterborne self-crosslinking polymer dispersions with biocidal effect. Pardubice: Chemagazin, 2017. ISBN 978-80906269-2-8.

4. Machotová J., Rückerová A.: Vodou ředitelné nátěry s novými kovalentně vázanými retardéry hoření. Chemické listy 2017, 111 (8), 541-544.

5. Foster A. B., Lovell P. A., Rabjohns M. A.: Control of adhesive properties through structured particle design of water-borne pressure-sensitive adhesives. Polymer 2009, 50 (7), 1654-1670. DOI: 10.1016/j.polymer.2009.01.054. ISSN 00323861.

6. Novák P.: Druhy koroze kovů. Koroze a ochrana materiálu 2005, 49 (4), 75-82.

7. Šňupárek J.: Makromolekulární chemie: úvod do chemie a technologie polymeru. Vyd. 3., dopl. a upr. Pardubice: Univerzita Pardubice, 2014. ISBN 978-80-7395-761-2.

8. Svoboda M.: Protikorozní ochrana kovu organickými povlaky, Praha: SNTL, 1985, $235 \mathrm{~s}$.

9. Kubátová H.: Nátěry kovů. Praha: Grada, 2000. ISBN 80247-9035-1.

10. Steinerová D., Kalendová A., Machotová J.: Preparation of environmentally harmless paints based on self-crosslinking acrylate latexes and assessment their industrial coating properties. Scientific Papers 2019, 25, 83-99.

11. Kalenda P., Veselý D., Antoš P.: Koroze a protikorozni ochrana kovových materiálu․ Pardubice: Univerzita Pardubice, 2003.

12 Kalendová A.: Metody testování vlastností organických povlakủ: Díl 1. Korozně-inhibični účinnost organických povlakí. Universita Pardubice: Pardubice, 2001.

13 Zhang D.-Q., He X.-M., Cai Q.-R.: pH and iodide ion effect on corrosion inhibition of histidine self-assembled monolayer on copper. Thin Solid Films 2010, 518, 2745 2749. 